\title{
The Effect of Prices, Halal Certification, and Halal Awareness on Buying Interest Among Muslims in Samarinda
}

\author{
Norvadewi $^{1^{*}}$, Camaria Dina ${ }^{1}$, Kokom Komariah $^{1}$, and Akhmad Nur Zaroni ${ }^{1}$ \\ ${ }^{1}$ Faculty of Islamic Economics and Business, State Islamic University (UIN) Samarinda, Indonesia
}

\begin{abstract}
Indonesia is a Muslim-majority country. A Muslim should pay attention to what they consume especially food and drink. Muslim consumers need to increase knowledge and awareness about halal food and beverage products. The existence of halal certification from MUI becomes one of the identities of a product ability to consume. In addition the price also affects the buying interest of consumers. This research aims to find out the influence of price, halal certification, and halal awareness on the interest in buying Chatime drinks among Muslims in Samarinda city. This is quantitative. The data collection technique uses questionnaires with a sample number of 100 people with probability sampling. Data analysis using multiple regression analysis. The results showed that halal certification did not affect Chatime beverage buying interest while prices and halal awareness affected buying interest. Simultaneously, price, halal certification, and halal awareness had a significant effect on Chatime's The coefficient of determination of $45.5 \%$ indicates the magnitude of the effect of independent variables on dependent variables while the remaining $54.5 \%$ is described by other variables outside of this study. It is necessary to socialize the importance of halal certification and the inclusion of halal certification in packaging and outlets.
\end{abstract}

\section{Introduction}

Indonesia is a majority country of Muslims. Islam is a religion that cares deeply about what its people consume. Every food and drink for a Muslim must be food and drink that is forbidden and not forbidden in the Qur'an and the hadith of the Prophet (Awan et al., 2015). Halal becomes one of the main things in food, medicine, cosmetics, and other consumer goods that can be eaten, used, or applied directly to the body of a Muslim. The products consumed should not contain ingredients that are considered haram for Muslims (Fahmi, 2017). This fact makes Indonesia a potential market for the development of the halal industry because Muslims must pay attention to what they consume, especially food and drink (Genoveva \&Utami, 2020).

The awareness of Muslims in Indonesia today regarding halal products has increased significantly. This is supported by data from the Indonesian Ulema Council (MUI) regarding

\footnotetext{
*Corresponding author: norvadewi@iain-samarinda.ac.id
} 


\section{$A I C \overline{C E B}$ Annual International Conference \\ on Islamic Economics and Business, 2021}

the increasing submission of halal certificate various products in Indonesia. Muslim consumers began to consume products that were good and useful even halal for them. Awareness of the importance of consuming halal products will have a significant impact on the interest in buying various halal products. When a Muslim has a good understanding of the concept of halal it will affect his consumption behavior and increase awareness to consume and buy halal products by Islamic teachings (Sahir et al., 2021). Halal food and drink are allowed to be eaten and drunk under Islamic sharia. The resulting halal must have halal certification to ensure halal. In addition, food safety and health reasons are also reasons for choosing halal food (Karimah \&Darwanto, 2021; Nurhasanah \&Hariyani, 2018).

Currently, the development of business in the field of food and beverage is very rapid, it is characterized by the increasing number of cafés and restaurants available, especially in major cities. Culinary in the form of drinks appeared such as Starbucks, Seven Elements, Sour Sally, and became a slang icon for the people of big cities. One of the famous beverage trends today is tea-based drinks in Chatime outlets. Chatime beverage is originating from Taiwan which has been operating since 2003 and is considered a Starbucks from Asia. Chatime outlets have spread in various countries such as the United States, Australia, Malaysia, India, the United Kingdom, the Philippines, Canada, Bangladesh, and Indonesia. Based on data in 2019 there are 275 Chatime outlets spread across various major cities in Indonesia (Ourstory.Id, March 18, 2020). This indicates that the buying interest in Chatime beverage products is quite high. In addition, Chatime drinks in Indonesia have been certified halal from MUI. This is certainly an attraction especially for Muslim consumers (Ourstory.id, May 27, 2021). In Samarinda, there are three Chatime outlets located in three large malls, namely Big Mall, Samarinda Square, and Samarinda Central Plaza.

There has been a lot of research on the effect of halal certification on buying interests such as Aziz \&Chok (2013); Fanny Putera Perdana et.al., (2019); Karimah \& Darwanto (2021); (Malik et al., 2019); Septiani \& Ridlwan (2020); Fawzeea et.al., (2021); Sahir et.al., (2021); Nugroho \& Atikah (2021); Setyaningsih \& Marwansyah (2019), the results of the study showed that halal certification has a positive and significant effect on buying interest. Afendi research (2020) found that halal certification has a positive but insignificant effect on buying interest even Nurhasanah \& Hariyani (2018) and Mahliza et.al., that halal certification has no significant effect on buying interest.

In addition to halal certification, awareness and level of understanding of the concept of halal for a Muslim will have a positive impact on behavior regarding matters that are subtle to them. This halal awareness will also affect the interest of the Muslim community to consume halal products ordered by Islam. Research on halal awareness of buying interests was conducted by Afendi (2020); Aziz \& Chok (2013); Fadlullah (2021); Izzuddin (2018); Karimah \& Darwanto (2021); Malik et.al., (2019); Miraza et.al., (2021); Novitasari et.al., (2021); Najmudin et.al., (2021); Nurhasanah \& Hariyani (2018); Sahir et.al., (2021); Septiani \& Ridlwan (2020); Setyaningsih \& Marwansyah (2019); Vizano et.al., (2021) where halal awareness has a positive and significant influence on buying interest, but Djunaidi et.al., (2021) research found that halal awareness does not affect the interest in buying halal products as well as Mahliza et.al. research,(2021) Found that halal awareness does not affect the interest in buying halal personal care products in the millennial Muslim women in Jakarta.

In addition to halal certification and halal awareness, prices become one of the determining factors both in bringing up buying interest and consumer purchasing decisions. Research on prices affecting buying interest was conducted by Ahmad Khalil (2021); Amron (2018); Stone et.al., (2020); Herlambang \& MM (2020); Lestari \& Rahmidani (2019); Puspitosari \& Suharso (2020); Wijantoro (2019); Gunawan \& Herdinata (2021) Wijaya \& Zulfa (2017). Research in Indawati Lestari et.al., (2021) found that price has a significant 


\section{$A I C \overline{I E B}$ Annual International Conference \\ on Islamic Economics and Business, 2021}

negative effect on buying interest while research Osly Usman \&Aryani (2020) and Pasaribu \& Purba (2020) shows that price does not affect buying interest.

Based on the results of the above research there is still a gap in the influence of price factors, halal certification, and halal awareness of buying interest, this study aims to test the influence of the above three factors on the interest in buying Chatime drinks among Muslims in Samarinda city.

\section{Literature Review}

\subsection{Buying Interest}

Buying interest is related to a consumer's intention in buying a particular product and how many products he needs at that time (Mustika Inong et al., 2021). According to Habibie et al., (2021) buying interest is the tendency of a consumer to buy something or take actions related to the purchase and is measured by the level of likelihood of a consumer making the purchase. Indicators of buying interest are as follows: (1) transactional interests, in the form of a consumer's tendency to buy a product; (2) interest reference, i.e. a person's tendency to refer products to others (Mustika Inong et al., 2021).

\subsection{Prices}

Price is the main thing that prospective consumers pay attention to when they want to buy a product. High or low prices will determine a person's buying an item. Through price, one can decide whether a product will be owned and consumed or vice versa (Annan et al., 2021; Puspitosari \& Suharso, 2020). Hawkins and Mothersbough define a price as the amount of money a person must pay for him or her to earn the right to use a product (Hawkins \&Mothersbaugh, 2010). Price is one of the competitive factors in marketing a product. Every company competes to offer attractive prices to consumers, so they want to buy the products they offer (Philip Kotler et al., 2005). Price indicators according to Kotler are as follows: (a). Affordability of prices; (b) Price conformity with product quality; (c) Price competitiveness; (d) The conformity of price with the benefits of production; (e) Price affects the customer's purchasing power; (f) Price can influence consumers in making decisions. (Philip Kotler et al., 2005).

\subsection{Halal Certification}

Certification of halal in food products, drugs, cosmetics, and other products is done to provide certainty of the status of idolatry, to reassure the consumer in consuming it. The continuity of the halal production process is guaranteed by the manufacturer by implementing the Halal Assurance System. The Decree of the Minister of Religious Affairs of the Republic of Indonesia Number 518 explains that halal certification is a written fatwa stating its halal food products issued by the Institute for Food, Medicine, and Cosmetic Studies, Indonesian Ulema Council (LPPOM MUI, n.d.). This halal certification shows whether a product is halal or not for a Muslim. This is also due to the large number of imported food products scattered in the markets of Muslim countries. This is what encourages the ending of halal certification for food products to be halal and safe for consumption by Muslim consumers. So halal certification becomes a very important factor in deciding the purchase of a product (Awan et al., 2015). Halal certification ensures safety for Muslim consumers to choose food that is good for them and follows religious rules. Food products that have halal certificates are products that meet safety and hygiene standards in the process 


\section{$A \mathrm{C} \overline{I E B}$ Annual International Conference \\ on Islamic Economics and Business, 2021}

of processing (Afendi, 2020) while according to Aziz \& Chok (2013) halal certification ensures safety for Muslims to consume a product. Halal certification is evidenced by the inclusion of halal logos on product packaging (Afendi, 2020).

\subsection{Halal Awareness}

Consciousness is the ability to feel aware of an event and object (Aziz \&chok, 2013). Halal awareness is the conscious state of a Muslim where he has sufficient knowledge of the concept of halal, how the process of slaughter is appropriate, and can choose halal products for their consumption. The more he understands the concept of halal; the more selective he is in buying and consuming food and beverage products that are widely sold in the community (Septiani \& Ridlwan, 2020). Halal awareness is also interpreted as the level of understanding of Muslims about the things that are subtle to them. According to Izzuddin (2018) and Najmuddin (2021), halal awareness is measured through the following initiators: (1) knowing what the concept of halal is, (2) knowing how the halal process is, (3) aware of the importance of consuming food and drink for itself.

\section{Method}

The method used in this research is quantitative descriptive which explains how the instrument influences the buying interest. There are 2 types of data used in this study, namely, primary and secondary data. The primary data in this study was taken by researchers by distributing questionnaires through google form to the Muslim community in Samarinda. While secondary data is the support of information from primary data that has been obtained. Secondary data of this study is obtained from previous research journals, books, articles, journals, and data related to this study. Population and sample in this study, the population size refers to the number of 724.698 people. The sample number in this study was 100 respondents using probability samplings. Probability sampling techniques provide equal opportunities for each member of the population to be selected as a sample. Data analysis techniques use multiple regression analysis.

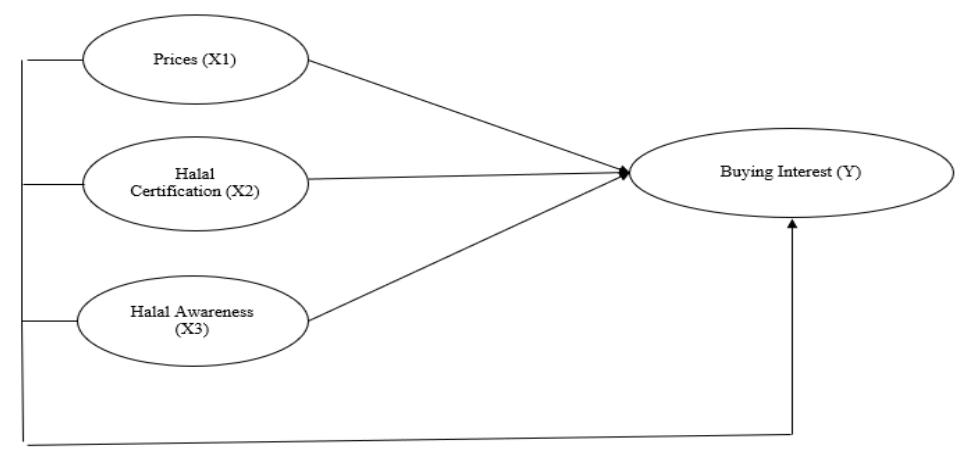

Figure 1. The Conceptual Framework

\section{Result}

Based on tests of normality, validity, and classical assumptions, this shows that the overall variables in the research model are valid and reliable, and free from the symptoms of classical 


\section{$A \overline{I F B}$ Annual International Conference \\ on Islamic Economics and Business, 2021}

assumptions (Appendix 1-5). Next is the hypothesis test, using partial tests and simultaneous tests. Based on partial tests in Table I showed, that the price has a significant value of 0.000 $<0.05$ and $t_{\text {calculated }}>t_{\text {table }} 8,282>1.984$ and halal awareness has the significance of $0.003<$ 0.05 and $t_{\text {calculated }} t_{\text {table }} 3.017>1.98498$ then Ha received, and Ho rejected then Ha is accepted, and Ho is rejected. That is, prices and halal awareness have a significant effect on the interest in buying Chatime drinks in the Muslim community of Samarinda city, while halal certification (significant value $0,186>0.05$ and $t_{\text {calculated }}<t_{\text {table }}-1,331<1,984$ ) Then Ha was rejected and Ho was accepted, meaning halal certification had a negative and not significant effect on the interest in buying Chatime drinks in the Muslim community in Samarinda City.

Table I. T-Test Value

Coefficients $^{\mathbf{a}}$

\begin{tabular}{|l|r|r|r|r|r|}
\hline \multirow{2}{*}{ Model } & \multicolumn{2}{|c|}{ Unstandardized Coefficients } & \multicolumn{1}{|c|}{$\begin{array}{c}\text { Standardized } \\
\text { Coefficients }\end{array}$} & \multirow{2}{*}{ Sig. } \\
\cline { 2 - 4 } & \multicolumn{1}{|c|}{ B } & Std. Error & \multicolumn{1}{c|}{ Beta } & & \\
\hline (Constant) &, 603 & 2,396 & &, 252 &, 802 \\
Prices &, 642 &, 078 &, 632 & 8,282 &, 000 \\
Halal Certification &,- 158 &, 119 &,- 119 & $-1,331$ &, 186 \\
Halal Awareness &, 400 &, 132 &, 265 & 3,017 &, 003 \\
\hline
\end{tabular}

a. Dependent Variable: Buying Interest

b. Source: Primary data processed

Source: Primary data processed

Then the test was conducted simultaneously, to test the influence of all variable prices, halal certification, halal awareness on the buying interest of Chatime drinks on the Muslim community of Samarinda city. Based on the results of the F Test in table II it can be seen that the value is 28,532 . With a probability of $0.05, \mathrm{df}=97(100-3)$ then $\mathrm{F}_{\text {table }}$ obtained by 2.70 , because the value $F_{\text {calculated }}(28.532)>F_{\text {table }}(2,70)$ and with a significance level of $0.000<$ 0.05 it can be concluded that $\mathrm{Ha}$ is accepted and Ho rejected which means prices, halal certification, and halal awareness have a significant effect on chatime's beverages in buying interest.

Table 2. F Test

ANOVA ${ }^{\mathrm{a}}$

\begin{tabular}{|cc|c|c|c|c|c|}
\hline & Model & Sum of Squares & Df & Mean Square & F & Sig. \\
\hline \multirow{2}{*}{1} & Regression & 260,653 & 3 & 86,884 & 28,532 &, $000^{\mathrm{b}}$ \\
& Residual & 292,337 & 96 & 3,045 & & \\
& Total & 552,990 & 99 & & & \\
\hline
\end{tabular}

a. Dependent Variable: Buying Interest

b. Predictors: (Constant), Halal Awareness, Prices, Halal Certification

Source: Primary data processed

Based on table 3 it can be seen that the value of the determination coefficient of 0.455 means that $45.5 \%$ of the dependent variables of buying interest can be explained by independent variables namely prices, halal certification, and halal awareness. The remaining 0,545 or $54.5 \%$ were explained by other factors not included in the study model. 


\section{$A I \overline{I F B}$ Annual International Conference \\ on Islamic Economics and Business, 2021}

Table 3. Coefficient Determinant

Model Summary

\begin{tabular}{|l|r|r|r|r|r|}
\hline Model & \multicolumn{1}{|c|}{$\mathrm{R}$} & R Square & Adjusted R Square & $\begin{array}{c}\text { Std. Error of the } \\
\text { Estimate }\end{array}$ & Durbin-Watson \\
\hline 1 &, $687^{7}$ &, 471 &, 455 & 1,74505 & 1,745 \\
\hline
\end{tabular}

a. Predictors: (Constant), Halal Awareness, Prices, Halal Certification

b. Dependent Variable: Buying Interest

Source: Primary data processed

Based on the output in table IV, the research equation is as follows:

$$
\mathrm{Y}=0,603+0,642 \mathrm{X}_{1}+(-0,158) \mathrm{X}_{2}+0,400 \mathrm{X}_{3}
$$

Information:

Y: Buying Interest

$\mathrm{X} 1$ : Prices

X2: Halal Certification

X3: Halal Awareness

It is known that the regression coefficient of buying interest $(\mathrm{Y})$ is 0.603 which means that if the value of the other variable remains (constant), then the buying interest is 0.603 units. Then, the price regression coefficient (X1) is 0.642 which means that every increase or decrease in the value of prices by 1 unit and the value of other variables remains (constant), then buying interest will increase or decrease by 0.642 units. Furthermore, the coefficient of halal certification regression (X2) is -0.158 which means that any increase or decrease in the value of halal certification by 1 unit and other variable values remain (constant), then the purchase decision will increase or decrease by -0.158 units. Finally, the halal awareness regression coefficient (X3) is 0.400 which means that any increase or decrease in the value of halal awareness by 1 unit and the value of other variables remains (constant), then the purchase decision will increase or decrease by 0.400 units.

Table 4. Multiple Linear Regression

Coefficients ${ }^{\mathrm{a}}$

\begin{tabular}{|c|c|c|c|c|c|c|}
\hline \multirow{2}{*}{\multicolumn{2}{|c|}{ Model }} & \multicolumn{2}{|c|}{$\begin{array}{c}\text { Unstandardized } \\
\text { Coefficients }\end{array}$} & $\begin{array}{l}\text { Standardized } \\
\text { Coefficients }\end{array}$ & \multirow[t]{2}{*}{$\mathrm{T}$} & \multirow[t]{2}{*}{ Sig. } \\
\hline & & $\mathrm{B}$ & Std. Error & Beta & & \\
\hline \multirow{4}{*}{1} & (Constant) & ,603 & 2,396 & & ,252 & ,802 \\
\hline & Prices & ,642 &, 078 & 632 & 8,282 &, 000 \\
\hline & Halal Certification &,- 158 & ,119 &,- 119 & $-1,331$ & , 186 \\
\hline & Halal Awareness & ,400 &, 132 & ,265 & 3,017 & ,003 \\
\hline
\end{tabular}

Dependent Variable: Buying Interest

Source: Primary data processed

\section{Discussion}

\subsection{The Influence of Prices on Buying Interest}




\section{$A I C \overline{I E B}$ Annual International Conference \\ on Islamic Economics and Business, 2021}

Based on the results of the test $\mathrm{t}$ (partial test) hypothesis X1 obtained that the price has a positive and significant influence on the interest in buying Chatime drinks in the Muslim community in Samarinda City. Testing the effect on price variables on buying interest can be found by looking at calculated by 8.282 and t table 1.98498 with a significant amount of 0.000 smaller than 0.05 than can show a positive and significant influence on the interest in buying Chatime drinks in the Muslim community in Samarinda city.

The results of this study are in line with the research of Ahmad Khalil (2021); Amron (2018); Stone et.al., (2020); Herlambang \& MM (2020); Lestari \& Rahmidani (2019); Puspitosari \& Suharso (2020); and Wijaya \& Zulfa (2017) that price becomes the main factor that affects consumer buying interest because the higher the price of a product, there will be less consumer buying interest in the product, and vice versa.

\subsection{The Influence of Halal Certification on Buying Interest}

Based on the test $\mathrm{t}$ (partial test) hypothesis $\mathrm{X} 2$ obtained that the halal certification variable has a negative and insignificant influence on the interest in buying Chatime drinks in the Muslim community in Samarinda City. Testing the effect of halal certification variables on buying interest can be known with a calculated value of -1.331 and $t$ table 1.98498 with a significant amount of 0.186 with a calculated $t$ value smaller than $t$ table and a significant value greater than 0.05 than can show a negative and insignificant influence on the interest in buying Chatime drinks in the Muslim community in Samarinda City. This shows that the Muslim community of Samarinda city has not considered halal certification in consuming a product.

The results of this study are in line with Nurhasanah \& Hariyani (2018) that halal certification has no significant effect on the interest in buying halal food products in Giant and Hypermart supermarkets in Yogya, and Alfamart and Indomart minimarkets in Jakarta, Bogor, Depok, Tangerang, and Bekasi. Similarly, Mahliza et.al.,(2021) research shows that halal certification has no significant effect on the interest in buying halal personal care products in millennial Muslim women in Jakarta.

This finding contradicts many previous studies that have found that halal certification has a positive and significant effect on buying interests such as Aziz \&Chok (2013); Karimah \& Darwanto (2021); (Malik et al., 2019); Septiani \& Ridlwan (2020); Setyaningsih \& Marwansyah (2019).

\subsection{The Influence of Halal Awareness on Buying Interest}

Based on the results of the test $\mathrm{t}$ (partial test) hypothesis X3 obtained that the halal awareness variable has a positive and significant influence on the interest in buying Chatime drinks in the Muslim community in Samarinda City. Testing on the halal awareness variable of buying interest can be known by looking at the value of $t$ calculated by 3.017 and $t$ table 1.98498 with a significant amount of 0.003 with a calculated value greater than the value of table and a significant value smaller than 0.05 than can show a positive and significant influence on the interest in buying Chatime drinks in the Muslim community in Samarinda City.

The results of this study are in line with research conducted by Afendi (2020); Aziz \& Chok (2013); Fadlullah (2021); Izzuddin (2018); Karimah \& Darwanto (2021); Malik et.al., (2019); Miraza et.al., (2021); Najmudin et.al., (2021); Nurhasanah \& Hariyani (2018); Sahir et.al., (2021); Septiani \& Ridlwan (2020); Setyaningsih \& Marwansyah (2019); Vizano et.al., (2021) where halal awareness has a positive and significant effect on buying interest. This explains that halal awareness is an understanding of Muslims towards the concept of halal, halal process, and halal principles that ultimately prioritize halal food for their consumption. With more understanding of the concept of halal, the process and 


\section{$A \mathrm{C} \overline{I E B}$ Annual International Conference \\ on Islamic Economics and Business, 2021}

principles of halal, Muslims tend to be more selective in choosing the products they consume. against the concept of halal, halal process, and halal principles that ultimately prioritize halal food and beverages for their consumption.

\subsection{The Influence of Prices, Halal Certification and Halal Awareness to Buying Interest}

Based on the results of the $F$ (simultaneous) test showed the value of $F_{\text {calculated }}$ at 28,532 this value is greater than the $F_{\text {table }}$ of 2.70 with a significant 0.000 because the value is smaller than 0.05 then the price, halal certification and halal awareness have a simultaneous and significant effect on the interest in buying Chatime drinks in the Muslim community in Samarinda City.

In buying interest there are three determinants together that affect Muslim society before deciding to buy a product. Consumers will buy Chatime beverage products taking into account first the interest in buying with the price, halal certification, and halal awareness with a percentage of $45.5 \%$. This is known by the determination coefficient $\left(\mathrm{R}^{2}\right)$ testing that has been done by obtaining results from price, halal certification, and halal awareness able to explain the influence on buying interest by $45.5 \%$. The remaining $54.5 \%$ was affected by other variables outside of the study.

\section{Conclusion}

Based on the results of research and data analysis showed that prices and halal awareness affect the purchase of Chatime drinks in the Muslim community in Samarinda city, while halal certification has a negative and not significant effect on the interest in buying Chatime drinks in the Muslim community of Samarinda city. This shows that the people of Samarinda already have halal awareness but have not considered halal certification in their iconic food and beverage products. It is necessary to socialize the importance of halal certification in food and beverage products and the inclusion of halal certification in food and beverage packaging and outlets.

\section{References}

Afendi, A. (2020). The Effect of Halal Certification, Halal Awareness and Product Knowledge on Purchase Decisions for Halal Fashion Products. Journal of Digital $\begin{array}{llll}\text { Marketing } \quad \text { Halal } & \text { Industry, } & \end{array}$ https://doi.org/10.21580/jdmhi.2020.2.2.6160

Ahmad Khalil, A. W., Fawa'id, M. W., \& Hidayah, L. (2021). Pengaruh Harga dan Label Halal Terhadap Minat Beli Roti Naf'a Di Kecamatan Kepung Kediri (The Influence of Price and Halal Labels on The Interest of Buying Naf'a Bread in Kepung Kediri). Qawãnïn: Journal of Economic Syaria Law, 5(1), 67-82. https://doi.org/10.30762/qawanin.v5i1.2760

Amron, A. (2018). Effects of Product Quality, Price, and Brand Image on the Buying Decision of City Car Product. Archives of Business Research, 6(4), 1-8. https://doi.org/10.14738/abr.64.4374

Annan, J., Donald, A., Goldstein, M., Gonzalez Martinez, P., \& Koolwal, G. (2021). Taking power: Women's empowerment and household Well-being in Sub-Saharan Africa. World Development, 140. https://doi.org/10.1016/j.worlddev.2020.105292

Awan, H. M., Siddiquei, A. N., \& Haider, Z. (2015). Factors Affecting Halal Purchase 


\section{$\mathrm{AIC} \overline{\mathrm{IEB}}$ Annual International Conference on Islamic Economics and Business, 2021}

Intention - Evidence from Pakistan's Halal food Sector. Management Research Review, 38(6), 640-660. https://doi.org/10.1108/mrr-01-2014-0022

Aziz, Y. A., \& Chok, N. V. (2013). The Role of Halal Awareness, Halal Certification, and Marketing Components in Determining Halal Purchase Intention Among NonMuslims in Malaysia: A Structural Equation Modeling Approach. Journal of International Food and Agribusiness Marketing, 25(1), 1-23. https://doi.org/10.1080/08974438.2013.723997

Batu, R. L., Monica, C., \& Aprilia, B. N. (2020). The Effect Of Promotion And Price On The Purchasing Decisions. Almana: Jurnal Manajemen Dan Bisnis, 4(1). https://doi.org/https://doi.org/10.36555/almana.v4i1.1290

Djunaidi, M., Oktavia, C. B. A., Fitriadi, R., \& Setiawan, E. (2021). Perception and Consumer Behavior of Halal Product Toward Purchase Decision in Indonesia. Jurnal Teknik Industri, 22(2), 171-184. https://doi.org/10.22219/jtiumm.vol22.no2.171-184

Fadlullah, A. K. (2021). The Effect of Halal Label, Halal Awareness, Food Ingredients, Advertising and Purchase Interest on the Decision To Buy "Samyang Noodles " ( Study on Universities Students in Malang City ). 24(2), 107-113. https://seajbel.com/wp-content/uploads/2021/05/SEAJBEL24_557.pdf

Fahmi, S. (2017). Halal labeling effect on muslim consumers attitude and behavior. November. https://doi.org/10.2991/icoi-17.2017.26

Fanny Putera Perdana, F., Jan, M. T., Altunişik, R., Jaswir, I., \& Kartika, B. (2019). the Role of Halal Certification on Purchase Intention Towards Food Products From Mena Countries: a Sem Study. Journal of Islamic Monetary Economics and Finance, 5(1), 63-88. https://doi.org/10.21098/jimf.v5i1.1048

Fawzeea, B. K., Sudardjat, I., \& Dilham, A. (2021). The Effective of Halal Certification and Product Quality Food Ingredients on the Interest of Buying through Experiential Buying of Consumers in Small Souvenir Industries Sumatera Utara. Systematic Reviews in Pharmacy, 12(3), 842-844. https://doi.org/10.31838/srp.2021.3.119

Genoveva, G., \& Utami, N. N. (2020). the Influence of Brand Image, Halal Label, and Halal Awareness on Customers Purchasing Decision of Halal Cosmetic. Jurnal Muara Ilmu Ekonomi Dan Bisnis, 4(2), 355. https://doi.org/10.24912/jmieb.v4i2.8381

Gunawan, N. F., \& Herdinata, C. (2021). The Effect of Price, Product Quality and Brand Image on the Interest in Purchasing Two Good Bakery Products. KnE Social Sciences, 2021, 282-296. https://doi.org/10.18502/kss.v5i5.8816

Hawkins, D. I., \& Mothersbaugh, D. L. (2010). Consumer Behaviour:Building Marketing Strategies. In McGraw-Hill. www.mhhe.com

Herlambang, R. T., \& MM, D. S. H. (2020). Analysis Price, Perception of Quality, and Promotion with Intervening Brand Trust Toward Purchase Intention Honda Vario 150CC (Case Study at PT Wahana Makmur Sejati). International Journal of Innovative Science and Research Technology, 5(8), 1276-1284. https://doi.org/10.38124/ijisrt20aug678

Indawati Lestari, Martin, Marihot Manullang, Ribka Sari Butar-Butar, \& Zulia Rifda Daulay. (2021). The Effect Of Brand Ambasador and Prices on The Purchase Decision Of Android Hand Phone Through Interest In Buying Consumers In Medan City. International Journal of Science, Technology \& Management, 2(4), 1321-1326. https://doi.org/10.46729/ijstm.v2i4.274

Izzuddin, A. (2018). Pengaruh Label Halal, Kesadaran Halal, dan Bahan Makanan Terhadap Minat Beli Makanan Kuliner. Jurnal Penelitian Ipteks, 3(2), 100-114. http://jurnal.unmuhjember.ac.id/index.php/PENELITIAN_IPTEKS/article/view/1886 $/ 1547$

Karimah, N., \& Darwanto, D. (2021). Effect of Halal Awareness, Halal Certification, Food Ingredients Composition, Halal Marketing and Religiosity on Purchase Intention of 


\section{$A I C \overline{I E B}$ Annual International Conference on Islamic Economics and Business, 2021}

Imported Food Products. Al-Kharaj : Jurnal Ekonomi, Keuangan \& Bisnis Syariah, 3(2), 177-191. https://doi.org/10.47467/alkharaj.v3i2.319

Lestari, S. A., \& Rahmidani, R. (2019). Pengaruh Harga Dan Word of Mouth (Wom) Terhadap Minat Beli Laptop Merek Toshiba Dikalangan Mahasiswa Universitas Negeri Padang. Jurnal Ecogen, 2(3), 524. https://doi.org/10.24036/jmpe.v2i3.7444

LPPOM MUI | Lembaga Pengkajian Pangan Obat-obatan dan Kosmetika Majelis Ulama Indonesia. (n.d.). Retrieved November 22, 2021, from https://www.halalmui.org/muil4/main/page/sertifikatketetapan-halal-mui

Mahliza, F., \& Prasetya, P. (2021). Determining Purchase Intention in Halal Personal Care Product: Study on Muslimah Millennial Generation. Jurnal Aplikasi Manajemen, 19(2), 319-334. https://doi.org/10.21776/ub.jam.2021.019.02.08

Malik, R. F., Hermawan, A., \& Asnawi, Y. H. (2019). the Effect of Halal Awareness, Halal Certification and Halal Marketing Toward Halal Purchase Intention of Fast Food Among Muslim Millenials Generation. Russian Journal of Agricultural and SocioEconomic Sciences, 90(6), 76-83. https://doi.org/10.18551/rjoas.2019-06.11

Miraza, M. F., Rini, E. S., \& . F. (2021). Halal Awareness, Social Media Promotion, and Reference Group (Word of Mouth) on Purchase Decision through Purchase Intention as Intervening Variable (Case Studies on MSME in Super Swalayan, Taman Setiabudi Indah, Medan). International Journal of Research and Review, 8(6), 347-354. https://doi.org/10.52403/ijrr.20210644

Mustika Inong, A., Hendradewi, S., \& Ratnaningtyas, H. (2021). Halal Label: Is It Important in Determining Buying Interest? JIMFE (Jurnal Ilmiah Manajemen Fakultas Ekonomi), 07(01), 1-10. https://doi.org/10.34203/jimfe.v7i1.2929

Najmudin, Syihabudin, \& Fatoni, A. (2021). The Effect Of Halal Awareness And Food Ingredients On Consumer Interests Of Culinary Seafood Beach Tourism. 12(1), 23-38. file:///D:/JURNAL LABEL HALAL, PRICE,/Halal Awareness Najmuddin.pdf

Novitasari, D., Chidir, G., Sutardi, D., Iskandar, J., \& Pebrina, E. T. (2021). The Role of Halal Awareness on Purchase Intention of Halal Food: Evidence from Indonesian Working Students. International Journal of Science and Management Studies (IJSMS), February, 31-44. https://doi.org/10.51386/25815946/ijsms-v4i1p104

Nugroho, A. A., \& Atikah, A. (2021). Halal Certification Models in Increasing Community Purchase Intention for Halal Products in Indonesia. Technology, and Organizational Behavior, 01(01), 23-34. https://ijbtob.org

Nurhasanah, S., \& Hariyani, H. F. (2018). Halal Purchase Intention on Processed Food. Tazkia Islamic Finance and Business Review, 11(2), 187-209. https://doi.org/10.30993/tifbr.v11i2.142

Osly Usman, M. B., \& Aryani, Y. (2020). The Effect Of Brand Image, Product Quality and Price on Purchase Intention. https://doi.org/https://dx.doi.org/10.2139/ssrn.3642536

Ourstory.id. (n.d.). Chatime Indonesia. Ourstory.Id. Retrieved November 23, 2021, from https://chatime.co.id/news/chatime-halal-dari-mui

Pasaribu, L. N., \& Purba, K. (2020). The Influence of Trust on the Online Purchase Decisions with Buying Interest on the Social Networking Site Instagram: Case Study of Online Shop Users on Instagram. Research, Society and Development, 9(10), e8669109119. https://doi.org/10.33448/rsd-v9i10.9119

Philip Kotler, Wong, Vv., Saunders, J., \& Armstrong, G. (2005). Principles of Marketing. Pearson Prentice Hall. https://doi.org/10.2307/2224326

Puspitosari, A. A., \& Suharso. (2020). The Effect of Products and Prices on Purchasing Decisions of Health Food. MEC-J (Management and Economics Journal), 4(2), 175184. https://doi.org/10.18860/mec-j.v4i2.9209

Sahir, S. H., Fahlevi, M., Kasbuntoro, \& Sutia, S. (2021). Effect of Halal Food Management System Certification on Buying Interest of Indonesian Consumer Goods. Uncertain 


\section{$A \mathrm{C} \overline{I E B}$ Annual International Conference \\ on Islamic Economics and Business, 2021}

Supply Chain Management, 9(3), 731-738. https://doi.org/10.5267/j.uscm.2021.4.005 Sejarah Waralaba Chatime, "Starbucks Dari Asia" - Ourstory.id. (n.d.). Ourstory.Id. Retrieved November 23, 2021, from https://ourstory.id/sejarah-waralaba-chatimestarbucks-dari-asia/

Septiani, D., \& Ridlwan, A. A. (2020). The Effects of Halal Certification and Halal Awareness on Purchase Intention of Halal Food Products in Indonesia. Indonesian Journal of Halal Research, 2(2), 55-60. https://doi.org/10.15575/ijhar.v2i2.6657

Setyaningsih, E. D., \& Marwansyah, S. (2019). The Effect of Halal Certification and Halal Awareness through Interest in Decisions on Buying Halal Food Products. Syi ar Iqtishadi: Journal of Islamic Economics, Finance and Banking, 3(1), 65. https://doi.org/10.35448/jiec.v3i1.5515

Vizano, N. A., Khamaludin, K., \& Fahlevi, M. (2021). The Effect of Halal Awareness on Purchase Intention of Halal Food: A Case Study in Indonesia. Journal of Asian Finance, Economics and Business, 8(4), 441-453. https://doi.org/10.13106/jafeb.2021.vol8.no4.0441

Wijaya, A. G., \& Zulfa, M. (2017). The Effect Of Word Of Mouth, Price, Perception, Brand Image, And Trust On Purchase Decision Using Purchase Intention As An Intervening Variable (Study at Middle Class Housing in Semarang). International Journal of Islamic Business Ethics, 2(3), 1. https://doi.org/10.30659/ijibe.2.3.1-12

Wijiantoro, D. S. (2019). The Influence of Product, Price, and Location on Consumer Purchasing Interest in Bakso Pak Kus Residen Sudirman Surabaya. Journal of World Conference (JWC), 1(1), 157-166. https://doi.org/10.29138/prd.v1i1.48 